\title{
Hilar Mossy Cells Provide the First Glutamatergic Synapses to Adult-Born Dentate Granule Cells
}

\author{
Jessica H. Chancey, ${ }^{1}$ David J. Poulsen, ${ }^{2}$ Jacques I. Wadiche, ${ }^{1}$ and Linda Overstreet-Wadiche ${ }^{1}$ \\ ${ }^{1}$ McKnight Brain Institute and Department of Neurobiology, University of Alabama at Birmingham, Birmingham, Alabama 35294 and ${ }^{2}$ Department of \\ Biomedical \& Pharmaceutical Sciences, University of Montana, Missoula, Montana 59812
}

Adult-generated granule cells (GCs) in the dentate gyrus must establish synapses with preexisting neurons to participate in network activity. To determine the source of early glutamatergic synapses on newborn GCs in adult mice, we examined synaptic currents at the developmental stage when NMDA receptor-mediated silent synapses are first established. We show that hilar mossy cells provide initial glutamatergic synapses as well as disynaptic GABAergic input to adult-generated dentate GCs.

Key words: adult neurogenesis; circuit; dentate gyrus; GABA; glutamate; synaptic

\section{Introduction}

Synaptic integration of adult-generated granule cells (GCs) has been well characterized as a multistage process that occurs over many weeks. Newborn GCs first receive synapses from local GABAergic interneurons in the first week after mitosis followed by glutamatergic synapses during the second and third postmitotic week (Espósito et al., 2005; Ge et al., 2006; Kumamoto et al., 2012). GABAergic innervation by interneurons that generate slow postsynaptic currents, like Ivy/Neurogliaform cells (Markwardt et al., 2011), is followed by innervation by perisomaticprojecting interneurons around the time when glutamatergic innervation is strengthening and outputs onto hilar neurons and CA3 pyramidal cells is established (Espósito et al., 2005; Faulkner et al., 2008; Gu et al., 2012). Synaptic integration continues over subsequent weeks, eventually resulting in functional connectivity that is indistinguishable from GCs generated in the postnatal period (Laplagne et al., 2006). Due to the role of the earliest synaptic connections in activity-dependent maturation and survival, recent attention has focused on the cellular identity of the initial synaptic partners (Markwardt et al., 2011; Song et al., 2012; Vivar et al., 2012; Deshpande et al., 2013).

Here we identify the source of early glutamatergic synapses on adult-generated neurons. Pro-opiomelanocortin-enhanced green florescent protein (POMC-EGFP) reporter mice label newborn GCs at an early developmental stage when the first NMDA receptor (NMDAR)-only silent synapses are established (Chancey et al., 2013). POMC-EGFP newborn GCs are 11-12 d postmitotic

Received Aug. 23, 2013; revised Dec. 13, 2013; accepted Jan. 2, 2014.

Author contributions: J.H.C., J.I.W., and L.O.-W. designed research; J.H.C. performed research; D.J.P. contributed unpublished reagents/analytic tools; J.H.C. analyzed data; J.H.C., J.I.W., and L.O.-W. wrote the paper.

This work was supported by NIH Grants T32NS061788, F31NS078887 (J.H.C.), R01NS064025 (L.0.-W.), R01NS065920 (J.I.W.), and P30 NS047466. We thank Drs. Thomas Van Groen, Inga Kadish, and Gwendalyn King for assistance with initial stereotaxic injections and members of the Wadiche labs for helpful comments throughout this project.

Correspondence should be addressed to either Dr. Linda Overstreet-Wadiche or Dr. Jacques I. Wadiche, University of Alabama at Birmingham, Department of Neurobiology, 1825 University Boulevard, Birmingham, AL 35294.E-mail: Iwadiche@uab.edu or jwadiche@uab.edu.

DOI:10.1523/JNEUROSCI.3620-13.2014

Copyright (C) 2014 the authors $\quad 0270-6474 / 14 / 342349-06 \$ 15.00 / 0$
(Overstreet-Wadiche et al., 2006a), consistent with retroviral labeling studies demonstrating that glutamatergic synapse formation initiates in the second week after retroviral infection (Ge et al., 2006; Kumamoto et al., 2012). POMC-EGFP newborn GCs have dendrites mainly restricted to the inner molecular layer (IML; Overstreet-Wadiche et al., 2006a,b); thus, glutamatergic terminals could arise from (1) hilar mossy cells (MCs) that form the associational/commissural pathway located in the IML, (2) projection neurons in the medial entorhinal cortex (MEC) that comprise the medial perforant path (MPP) located in the middle molecular layer (MML) that may also impinge into the IML, or (3) mossy fibers (MFs) from mature GCs (Vivar et al., 2012). We use pharmacology and optogenetics to distinguish between these possibilities.

\section{Materials and Methods}

Adult ( $>8$ weeks old) female hemizygous POMC-EGFP transgenic mice (Cowley et al., 2001; Overstreet et al., 2004) were maintained on a C57BL/6J background. Animal procedures followed the Guide for the Care and Use of Laboratory Animals, U.S. Public Health Service, and were approved by the University of Alabama at Birmingham Institutional Animal Care and Use Committee. Mice were housed in an enriched environment.

The pAAV-hSyn-hChR2(H134)-mCherry construct from K. Deisseroth (Stanford University, Stanford, CA) was purchased from Addgene (plasmid 26976) and packaged into recombinant adenoassociated virus (AAV8) with a titer of $6 \times 10^{13}$ genomic particles $/ \mathrm{ml}$. Approximately $1.5 \times 10^{7}$ HEK $293 \mathrm{~T}$ cells were seeded in complete DMEM (Cellgro) with 10\% fetal bovine serum, 1 mM MEM sodium pyruvate, $0.1 \mathrm{~mm}$ MEM nonessential amino acids solution, and $0.05 \%$ Penicillin-Streptomycin $(5000 \mathrm{U} / \mathrm{ml})$. After $24 \mathrm{~h}$, media was changed to culture media containing $5 \%$ fetal bovine serum, and cells were transfected with three plasmids: Adeno helper plasmid (pF $\Delta 6$ ), AAV helper encoding serotype 8 (pAR-8 obtained from Miguel Senna Estevez (University of Massachusetts Medical School, Worcester, MA) (Broekman et al., 2006), and the AAV transgene vector containing the hSyn-hChR2(H134)-mCherry expression cassette flanked by the AAV2 inverted terminal repeats. Plasmids were transfected using Polyfect (Qiagen). Cultures were incubated at $37^{\circ} \mathrm{C}, 5 \% \mathrm{CO}_{2}$ for $72 \mathrm{~h}$, and then pelleted by centrifugation and resuspended in $10 \mathrm{~mm}$ Tris, 
pH 8.0. Cells were lysed by three freeze-thaw cycles in a dry ice-ethanol bath followed by treatment with $50 \mathrm{U}$ benzonase (Novagen) and $0.5 \%$ sodium deoxycholate for $30 \mathrm{~min}$ at $37^{\circ} \mathrm{C}$, and then three sonication cycles. Virus was purified by density gradient centrifugation in iodixinol according to the method of Zolotukhin et al. (1999). Purified virus preparations were concentrated and desalted in sterile artificial CSF (ACSF) by centrifugation in Millipore Ultrafree 15 filter devices. The titer of each virus (genomic particles/ $\mathrm{ml}$ ) was determined by quantitative reverse transcriptase-PCR using primers and a probe specific for the WPRE (woodchuck hepatitis post-transcriptional regulatory element) sequence. The AAV2-hSyn-hChR2(H134)EYFP ( $10^{12}$ titer) from K. Deisseroth was purchased from the University of North Carolina Vector Core.

Mice were anesthetized with ketamine (50 $\mathrm{mg} / \mathrm{kg})$ and medetomide $(0.5 \mathrm{mg} / \mathrm{kg})$. Coordinates from bregma to target the hilus were 3.00 $\mathrm{mm}$ posterior and $2.50-2.70 \mathrm{~mm}$ lateral, and $0.2 \mu \mathrm{l}$ of virus was injected at each of two depths: 3.00 and $2.70 \mathrm{~mm}$ from dura. Coordinates to target the MEC were $3.80 \mathrm{~mm}$ poste-

rior, $4.00 \mathrm{~mm}$ lateral, and 3.40 and $3.20 \mathrm{~mm}$ deep. Mice were given intraperitoneal injections of Buprenex $(0.1 \mathrm{mg} / \mathrm{kg})$ and Atipamezole $(0.25 \mathrm{mg} / \mathrm{kg})$, and $1 \mathrm{ml}$ of warm saline subcutaneously.

Three to 8 weeks after injections, horizontal hippocampal slices were prepared (Chancey et al., 2013). Slices were bathed in $\sim 32^{\circ} \mathrm{C}$ ACSF containing the following (in $\mathrm{mm}$ ): $125 \mathrm{NaCl}, 2.5 \mathrm{KCl}, 1.25$ $\mathrm{Na}_{2} \mathrm{PO}_{4}, 2 \mathrm{CaCl}_{2}, 1 \mathrm{MgCl}_{2}, 25 \mathrm{NaHCO}_{3}$, and $25 \mathrm{D}$-glucose bubbled with $95 \% \mathrm{O}_{2} / 5 \% \mathrm{CO}_{2}$, at a rate of $>2 \mathrm{ml} / \mathrm{min}$. For most experiments, whole-cell recording pipettes contained the following (in $\mathrm{mM}$ ): 120 Cs-gluconate, $17.5 \mathrm{CsCl}, 4 \mathrm{MgCl}_{2}, 10$ HEPES, $4 \mathrm{Mg}$-ATP, $0.3 \mathrm{Na}-$ GTP, 7 phosphocreatine, and 10 EGTA, pH 7.2. The [CsCl] was reduced to $1.2 \mathrm{~mm}$ for experiments (see Fig. 4). For channelrhodopsin (ChR2)-expressing cells (see Fig. 2A), patch pipettes contained the following (in $\mathrm{mm}$ ): $150 \mathrm{~K}$ gluconate, $1 \mathrm{MgCl}_{2}$, 1.1 EGTA, 5 HEPES, 10 phosphocreatine, $0.2 \%$ biocytin, $\mathrm{pH} 7.2$. Synaptic stimulation was delivered using a patch pipette filled with ACSF and a constant current stimulator (Digitimer, Ltd.). Initial experiments used full-field illumination controlled by a Smart Shutter (Sutter Instruments) and a mercury lamp with a GFP filter set (Semrock; see Fig. 2). Subsequent experiments used a $455 \mathrm{~nm}$ LED mounted in the epifluorescence light path controlled by an external driver (DC2100; ThorLabs). Series resistance was uncompensated $(8-35 \mathrm{M} \Omega$ ), and junction potentials were not corrected. Recordings were filtered at $2 \mathrm{kHz}$ and sampled at $10 \mathrm{kHz}$ (MultiClamp 700B; Molecular Devices). Data were acquired and analyzed with AxoGraph X (AxoGraph Scientific) and Prism (GraphPad Software).

After recordings, slices were processed as described previously (Markwardt et al., 2011; Chancey et al., 2013) using a combination of streptavidin-Alexa Fluor 647 (1:1000; Life Technologies), Living Colors DsRed polyclonal antibody (1:1000; Clontech), anti-GFP Alexa Fluor 488 (1:1000; Life Technologies), and goat anti-rabbit Alexa Fluor 568 (1:400; Life Technologies).

\section{Results}

Pharmacological identification of IML- and MPP-evoked EPSCs

To confirm the pharmacological signature of glutamate release from MCs and MPP terminals, we first recorded EPSCs from mature GCs while stimulating in the IML or MML, respectively. MPP terminals contain Group II mGluRs that decrease release probability (Macek et al., 1996; Kilbride et al., 2001;
Chiu and Castillo, 2008). Thus, the Group II mGluR agonist $(2 S, 20 R, 30 R)$-2-[20,30-dicarboxycyclopropyl] glycine (DCG$\mathrm{IV} ; 1 \mu \mathrm{M})$ reduced MML-evoked EPSCs and increased the paired-pulse ratio (PPR; Fig. $1 A ; 69 \pm 4 \%$ reduction; PPR: $0.87 \pm 0.07$ to $1.35 \pm 0.10, p<0.01$, paired $t$ test $)$. IMLevoked EPSCs, however, were minimally affected by DCG-IV $(21 \pm 11 \%$ reduction, $p<0.001$ compared with MML EPSCs, ANOVA with post hoc Bonferroni; PPR: $0.92 \pm 0.11$ to $0.94 \pm$ $0.14, p=0.45$ ). Conversely, MC terminals contain presynaptic type I cannabinoid (CB1) receptors (Chiu and Castillo, 2008). The CB1 agonist WIN 55,212-2 (WIN; $5 \mu \mathrm{M}$ ) selectively reduced IML-evoked EPSCs compared with MML-evoked EPSCs (Fig. $1 B ; 61 \pm 10 \%$ reduction compared with $20 \pm 9 \%$, respectively, $p<0.01$ ), and increased the PPR of IML-evoked EPSCs (IML: $0.90 \pm 0.04$ to $1.36 \pm 0.19, p<0.05$; MML: $0.88 \pm 0.06$ to $0.94 \pm$ $0.10, p=0.25$, data not shown). Pharmacologically isolated NMDAR mediated ESPCs evoked by IML stimulation (recorded at $+40 \mathrm{mV}$ ) were blocked by WIN to a similar extent (78 $\pm 3 \%$ block, $n=4, p>0.05$; data not shown). Thus, sensitivity to DCG-IV and WIN can be used to distinguish between glutamate release from MPP and MC terminals.

We next tested the pharmacological sensitivity of glutamate release onto POMC-EGFP newborn GCs. Since glutamatergic transmission at this stage is primarily mediated by NMDARs (Chancey et al., 2013), we monitored glutamatergic release at $+40 \mathrm{mV}$ in response to focal stimulation near newborn GC dendrites. We detected small-amplitude NMDAR EPSCs in 50 of 92 cells $(8.7 \pm 1.3 \mathrm{pA})$. NMDAR EPSCs were relatively insensitive to the $\mathrm{mGluR}$ agonist DCG-IV (Fig. 1A; $21 \pm 5 \%$ reduction, $p>0.05$ compared with IML EPSCs in mature GCs) but were reduced by the CB1 agonist WIN (Fig. $1 B ; 61 \pm 4 \%$ reduction, $p>0.05$ compared with IML-evoked EPSCs in mature GCs). In addition, WIN increased the PPR from $0.78 \pm 0.09$ to $1.21 \pm 0.19(p<0.05)$, whereas DCG-IV had no effect on PPR $(0.74 \pm 0.06$ to $0.70 \pm 0.05, p=0.32)$. These results suggest that the initial glutamatergic input to adult-born GCs is from MCs. Since MF synapses from mature GCs also express Group II mGluRs (Manzoni et al., 1995; 

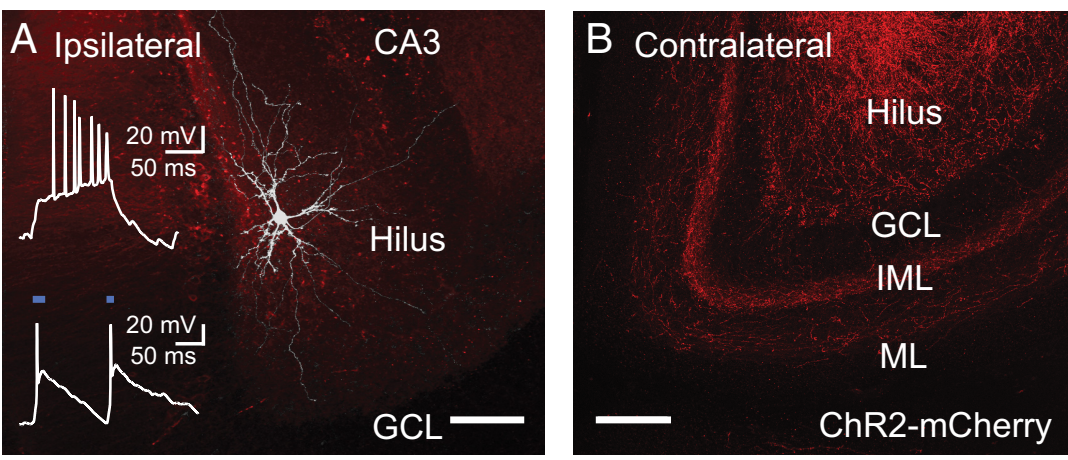

C Contralateral mature GC $455 \mathrm{~nm}$
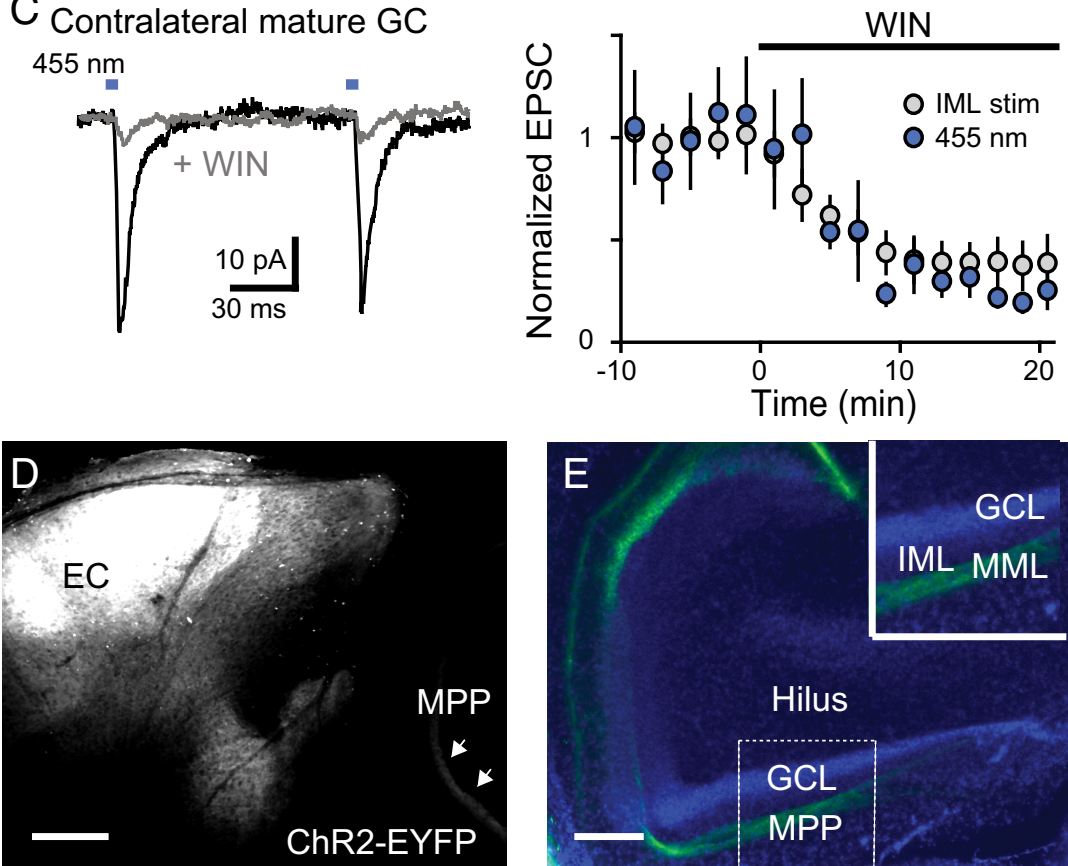

F Ipsilateral mature GC

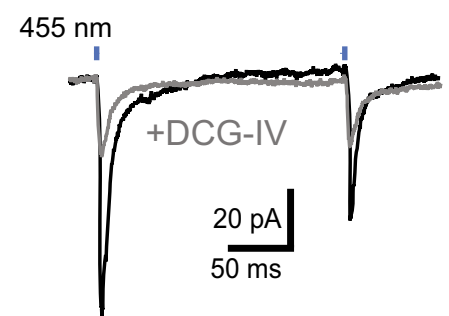

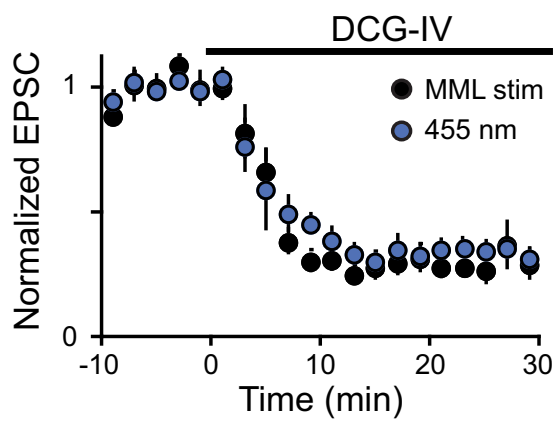

Figure 2. ChR2-mediated glutamate release. $\boldsymbol{A}$, ChR2-mCherry expression (red) in an injected (ipsilateral) DG with a MC filled with biocytin (white). Insets, MC spiking in response to current steps (top, 200 pA, $200 \mathrm{~ms}$ ) or $455 \mathrm{~nm}$ light (blue). Scale bar, 100 $\mu \mathrm{m} . \mathrm{GCL}$, granule cell layer. $\boldsymbol{B}$, ChR2-mCherry-labeled commissural MC axons in the hilus and IML of the contralateral DG. Scale bar, $100 \mu \mathrm{m}$. C, Light-evoked EPSCs recorded from a mature GC before (black) and after (gray) WIN. WIN sensitivity was similar for light-evoked $(n=4)$ and IML electrically evoked EPSCs $(n=9$; data from Fig. 1B). D, ChR2-EYFP expression in the MPP (arrows) following injection into the entorhinal cortex (EC). Scale bar, $100 \mu \mathrm{m}$. E, ChR2-EYFP expression (green) in the MPP. GCs are labeled with DAPI (blue). Scale bar, $50 \mu \mathrm{m}$. F, Light-evoked EPSCs in a mature GC before (black) and after (gray) DCG-IV. DCG-IV sensitivity was similar for light-evoked $(n=3)$ and MML electrically evoked EPSCs $(n=9$; data from Fig. $1 A)$.

Kwon and Castillo, 2008), these results also argue against the possibility that the earliest innervation arises from neighboring mature GCs (Vivar et al., 2012).

\section{Optogenetic activation of MCs and MPP}

To selectively activate MCs, we injected AAV carrying synapsin promoter-driven ChR2 tagged with either mCherry (ChR2-
mCherry) or EYFP (ChR2-EYFP) into the right hilus of POMC-EGFP mice. Many cells near the injection site were infected, including MCs, interneurons, and GCs (Fig. 2A). MCs that expressed ChR2 were identified by characteristic morphology including thorny excrescences and physiological properties including a high frequency of spontaneous EPSPs and nonaccommodating action potentials (APs) with little afterhyperpolarization (Scharfman and Myers, 2012). ChR2-expressing MCs depolarized in response to brief pulses of blue light and fired APs (Fig. 2A, inset). AP firing, but not ChR2-mediated depolarization, was blocked by TTX (data not shown).

MCs project axons along the septotemporal axis to distal areas of the ipsilateral dentate gyrus (DG; associational pathway) and to the contralateral DG (Ribak et al., 1985; Ratzliff et al., 2004; Scharfman and Myers, 2012; commissural pathway). We found robust ChR2 expression in the hilus and IML of the contralateral (left) DG (Fig. $2 B)$. In the presence of the $\mathrm{GABA}_{\mathrm{A}}$ receptor antagonist picrotoxin (PTX), blue light pulses (1 or $10 \mathrm{~ms}$ ) evoked EPSCs in mature GCs (Fig. 2C). Light-evoked EPSCs were blocked by WIN to a degree similar to that of electrically evoked IML EPSCs (70 \pm $6 \%$ reduction; $n=4 ; p>0.05)$. Furthermore, light-activated NMDAR EPSCs recorded at $+40 \mathrm{mV}$ were blocked by WIN to a similar extent $(67 \pm 10 \%$ block, $n=4, p>0.05$; data not shown).

We also injected AAV-ChR2 into the entorhinal cortex to drive expression in the MPP, resulting in axonal labeling in the MML of the ipsilateral DG (Fig. 2D,E). Light-evoked EPSCs in mature GCs were sensitive to DCG-IV to an extent similar to electrically evoked MML EPSCs (Fig. $2 F, 66 \%$ reduction, $n=3, p>0.05$ ). Thus, ChR2 can be used to selectively activate extrahippocampal and intrahippocampal excitatory inputs (Kumamoto et al., 2012).

\section{Mossy cells innervate newborn GCs}

To determine whether selective activation of MCs could evoke EPSCs in newborn GCs, we first found contralateral slices with sufficient MC axonal ChR2 expression to evoke light-activated EP$\mathrm{SCs}$ in mature GCs (as in Fig. 2B,C). Light-evoked EPSCs were smaller than electrically evoked EPSCs (Fig. $3 A ; 34 \pm 6$ pA and $128 \pm 27$ $\mathrm{pA}$, respectively; $p<0.01$, paired $t$ test, $n=15$ ), suggesting that not all IML fibers expressed ChR2. After testing for ChR2 expression by first recording from mature GCs, we subsequently identified neighboring newborn GCs that had electrically evoked NMDAR EPSCs (Fig. 3A, bottom). Under these conditions, we found light-activated EPSCs in $62 \%$ of newborn GCs (13 of 21 
cells), confirming MCs provide early glutamatergic inputs. Light-activated responses in newborn GCs were blocked by NBQX and AP5 ( $n=3$; data not shown), as well as WIN $(n=4)$. Unlike mature GCs, light-activated EPSCs in newborn GCs had the same amplitude as electrically evoked EPSCs ( $12 \pm 2 \mathrm{pA}$ and $15 \pm 3$ $\mathrm{pA} ; p=0.3$, paired $t$ test, $n=9)$, indicative of the largely all-or-none nature of the initial glutamatergic inputs (Chancey et al., 2013).

To determine whether MPP also contributes to glutamate release to newborn GCs, we followed the same experimental paradigm with MEC-injected mice. We first found ipsilateral slices with sufficient MPP ChR2 expression to induce light-evoked EPSCs in mature GCs (Fig. 3B; $30 \pm 11$ pA compared with $145 \pm 20 \mathrm{pA}$ for electrically evoked EPSCs; $n=14, p<0.001)$. In neighboring newborn GCs that had EPSCs evoked by electrical stimulation, we never detected light-activated EPSCs (Fig. 3B, bottom; 0 of 14 cells). In addition, ChR2 expression in the lateral perforant path did not drive EPSCs in newborn GCs $(n=0$ of 6 ; data not shown), suggesting that connectivity to the perforant path was not yet established.

\section{Mossy cells drive GABA release onto newborn GCs}

Although the MPP does not innervate $\mathrm{POMC}-\mathrm{EGFP}^{+}$newborn GCs, MPP stimulation can provide depolarization through feedforward GABA release (Overstreet Wadiche et al., 2005). We therefore asked whether MCs could also provide GABA release to newborn GCs. In contralateral slices from AAV-ChR2 hilar-injected mice (in the absence of PTX), we first found that light evoked both EPSCs (recorded at $E_{\mathrm{GABA}}=-70$ $\mathrm{mV}$ ) and IPSCs (recorded at $E_{\text {glutamate }}=0$ $\mathrm{mV}$ ) in mature GCs. Consistent with MCevoked disynaptic inhibition of GCs (Jinde et al., 2012), light-evoked IPSCs were completely blocked by either NBQX or PTX (Fig. $4 A ; n=4$ and 3, respectively). Neighboring newborn GCs also showed light-evoked disynaptic $\mathrm{GABA}_{\mathrm{A}}$ receptor-mediated PSCs that were blocked by either NBQX or PTX (Fig. $4 B ; n=3$ and 4 , respectively). In PTX, subsequent recording at $+40 \mathrm{mV}$ revealed monosynaptic NMDA EPSCs (Fig. 4B, bottom). Thus, MCs generate both monosynaptic glutamate and disynaptic GABA release to newborn GCs. As expected, the latency of disynaptic GABA PSCs was longer than that of monosynaptic NMDAR EPSCs (6.7 \pm $1.4 \mathrm{~ms}$ vs $3.4 \pm 0.5 \mathrm{~ms}, p<0.05)$. Yet, the duration of GABA PSCs and NMDA EPSCs was similar (Fig. $4 C$; decay $\tau=78 \pm$ 15 vs $81 \pm 11 \mathrm{~ms}, p=0.8 ; n=7$ and 10 ), suggesting that MC-evoked GABAergic depolarization could potentially con-

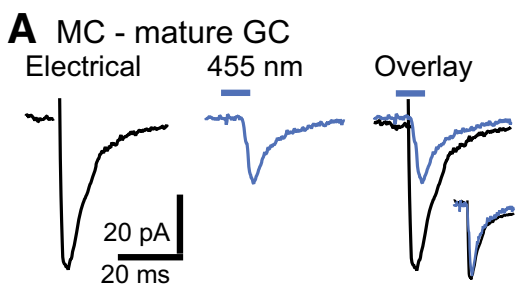

B MEC - mature GC Electrical $\quad 455 \mathrm{~nm}$
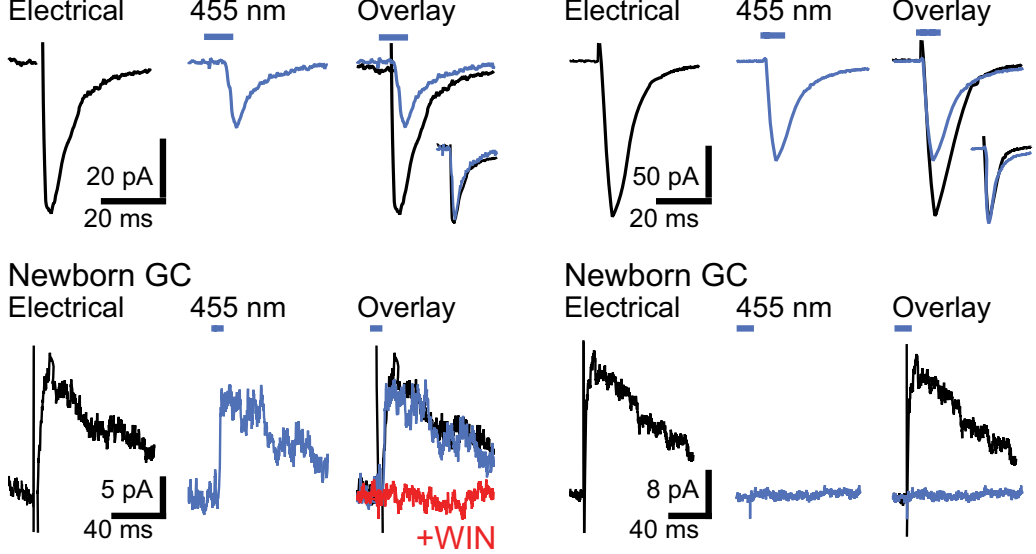

Newborn GC

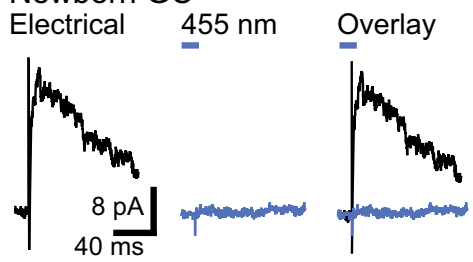

Figure 3. MC activation evokes EPSCs in newborn GCS. A, Top, EPSCs in a mature GC evoked by electrical stimulation in the IML (left) or light stimulation of MCs (middle; $10 \mathrm{~ms}$ ). The overlay (right) shows that light-evoked responses were smaller than located near the mature $\mathrm{GC}$ in $\boldsymbol{A}$. In newborn GCs the amplitude of light-evoked EPSCs was similar to that of electrically evoked EPSCs, and light-evoked EPSCs were blocked by WIN. $\boldsymbol{B}$, Top, electrically evoked and light-evoked MPP EPSCs in a mature GC.
A Mature GC
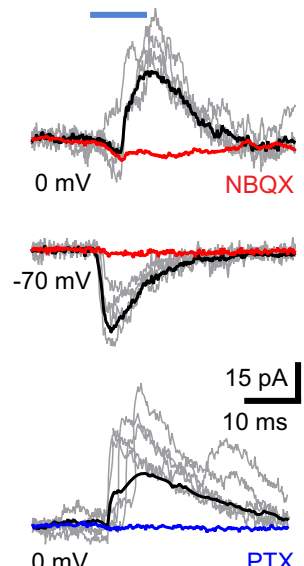

PTX
B Newborn GC
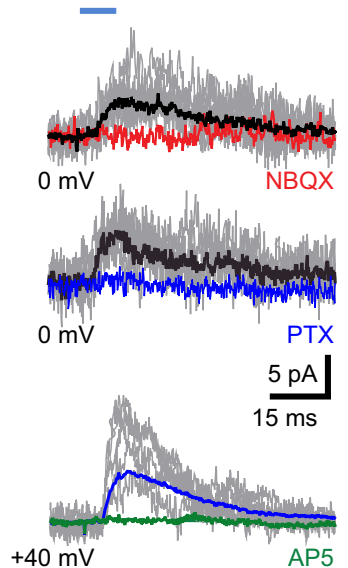

C Newborn GC
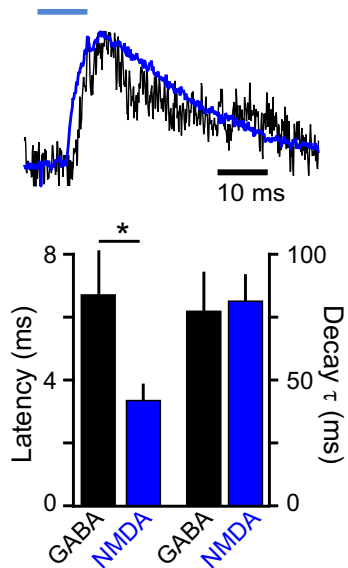

Figure 4. MCs generate disynaptic GABA release. $A$, Light stimulation of MC axons generated NBQX-sensitive ( $5 \mu \mathrm{m}$; red) IPSCs (top; $0 \mathrm{mV}=\mathrm{E}_{\text {glutamate }}$ ) and monosynaptic EPSCs (middle; $-70 \mathrm{mV}=\mathrm{E}_{\mathrm{GABA}}$ ) in mature $\mathrm{GCS}$. Bottom, light-evoked disynaptic IPSCs were also blocked by PTX (100 $\mu \mathrm{m}$; blue). Individual traces (gray) are overlaid with the average (black). $\boldsymbol{B}$, Light stimulation PTX revealed NMDA EPSCs blocked by AP5 ( $50 \mu \mathrm{m}$; green, $n=2)$. C, The NMDA EPSC and GABA PSC from the same newborn GC are overlaid to show the similar time course.

tribute to relief of the voltage-dependent $\mathrm{Mg}^{2+}$ block at initially silent MC synapses (Chancey et al., 2013).

\section{Discussion}

Hilar MCs are innervated by the perforant path, CA3 pyramidal cells, and GC MFs and, in turn, provide translaminar excitatory connections in the septo-temporal axis to ipsilateral and contralateral GCs and interneurons (Williams et al., 2007; Scharfman and Myers, 2012; Jinde et al., 2013). Our results show that MCs are poised to translate intrahippocampal and extrahippocampal activity to adult-born neurons during a critical period for survival when the first excitatory synapses are established (Chancey et al., 2013).

Consistent with our findings, Kumamoto et al. (2012) reported EPSCs arising from both MCs and perforant path axons in newly generated GCs at $14 \mathrm{~d}$ post-retroviral labeling. 
Rabies virus-mediated trans-synaptic tracing also reveals time-dependent innervation from multiple cell types and brain areas. Vivar et al. (2012) show trans-synaptic labeling from 21-d-old GC cells in hilar MCs, local interneurons, astrocytes, and the entorhinal cortex. Surprisingly, they also found evidence for transient innervation from mature GCs and CA3 pyramidal cells. We found no functional evidence for innervation by mature GCs, but we cannot rule out a potential contribution by CA3 cells that can project to the IML (Li et al., 1994). Our results are consistent with trans-synaptic viral labeling of hilar MCs during the second postmitotic week followed by MEC labeling in the third postmitotic week (Deshpande et al., 2013). Since mechanisms of viral tracing are unclear and synaptic signaling can occur via spillover from distantly located release sites (Markwardt et al., 2009, 2011; Capogna and Pearce, 2011; Coddington et al., 2013), a combination of functional and anatomical approaches provides the clearest understanding of synaptic communication.

Our results suggest that MCs play an important role in regulating neurogenesis by providing early glutamatergic synapses to newly generated GCs. At this developmental stage, GABAergic depolarization allows NMDAR activation required for AMPA receptor incorporation at silent synapses (Chancey et al., 2013), suggesting a need for coordinated GABAergic and glutamatergic signaling. MC-evoked disynaptic GABA signaling to newborn GCs thus potentially provides the circuitry to synchronize glutamate and GABA release for activity-dependent synapse unsilencing (Chancey et al., 2013). Interestingly, selective loss of MCs impairs pattern separation (Jinde et al., 2012), a DG-associated task that has been linked to adult-born neurons (Clelland et al., 2009; Sahay et al., 2011; Nakashiba et al., 2012; Niibori et al., 2012). MC innervation of adult-generated neurons could also promote the participation of adult-generated neurons in DG network activity.

\section{References}

Broekman ML, Comer LA, Hyman BT, Sena-Esteves M (2006) Adenoassociated virus vectors serotyped with AAV8 capsid are more efficient than AAV-1 or -2 serotypes for widespread gene delivery to the neonatal mouse brain. Neuroscience 138:501-510. CrossRef Medline

Capogna M, Pearce RA (2011) GABA $_{\mathrm{A}, \text { slow: }}$ causes and consequences. Trends Neurosci 34:101-112. CrossRef Medline

Chancey JH, Adlaf EW, Sapp MC, Pugh PC, Wadiche JI, Overstreet-Wadiche LS (2013) GABA depolarization is required for experience-dependent synapse unsilencing in adult-born neurons. J Neurosci 33:6614-6622. CrossRef Medline

Chiu CQ, Castillo PE (2008) Input-specific plasticity at excitatory synapses mediated by endocannabinoids in the dentate gyrus. Neuropharmacology 54:68-78. CrossRef Medline

Clelland CD, Choi M, Romberg C, Clemenson GD Jr, Fragniere A, Tyers P, Jessberger S, Saksida LM, Barker RA, Gage FH, Bussey TJ (2009) A functional role for adult hippocampal neurogenesis in spatial pattern separation. Science 325:210-213. CrossRef Medline

Coddington LT, Rudolph S, Vande Lune P, Overstreet-Wadiche L, Wadiche JI (2013) Spillover-mediated feedforward inhibition functionally segregates interneuron activity. Neuron 78:1050-1062. CrossRef Medline

Cowley MA, Smart JL, Rubinstein M, Cerdán MG, Diano S, Horvath TL, Cone RD, Low MJ (2001) Leptin activates anorexigenic POMC neurons through a neural network in the arcuate nucleus. Nature 411:480-484. CrossRef Medline

Deshpande A, Bergami M, Ghanem A, Conzelmann KK, Lepier A, Gotz M, Berninger B (2013) Retrograde monosynaptic tracing reveals the temporal evolution of inputs onto new neurons in the adult dentate gyrus and olfactory bulb. Proc Natl Acad Sci U S A 110:E1152-E1161. CrossRef

Espósito MS, Piatti VC, Laplagne DA, Morgenstern NA, Ferrari CC, Pitossi FJ, Schinder AF (2005) Neuronal differentiation in the adult hippocam- pus recapitulates embryonic development. J Neurosci 25:10074-10086. CrossRef Medline

Faulkner RL, Jang MH, Liu XB, Duan X, Sailor KA, Kim JY, Ge S, Jones EG, Ming GL, Song H, Cheng HJ (2008) Development of hippocampal mossy fiber synaptic outputs by new neurons in the adult brain. Proc Natl Acad Sci U S A 105:14157-14162. CrossRef

Ge S, Goh EL, Sailor KA, Kitabatake Y, Ming GL, Song H (2006) GABA regulates synaptic integration of newly generated neurons in the adult brain. Nature 439:589-593. CrossRef Medline

Gu Y, Arruda-Carvalho M, Wang J, Janoschka SR, Josselyn SA, Frankland PW, Ge S (2012) Optical controlling reveals time-dependent roles for adult-born dentate granule cells. Nat Neurosci 15:1700-1706. CrossRef Medline

Jinde S, Zsiros V, Jiang Z, Nakao K, Pickel J, Kohno K, Belforte JE, Nakazawa K (2012) Hilar mossy cell degeneration causes transient dentate granule cell hyperexcitability and impaired pattern separation. Neuron 76:1189_ 1200. CrossRef Medline

Jinde S, Zsiros V, Nakazawa K (2013) Hilar mossy cell circuitry controlling dentate granule cell excitability. Front Neural Circuits 7:14. CrossRef Medline

Kilbride J, Rush AM, Rowan MJ, Anwyl R (2001) Presynaptic group II mGluR inhibition of short-term depression in the medial perforant path of the dentate gyrus in vitro. J Neurophysiol 85:2509-2515. Medline

Kumamoto N, Gu Y, Wang J, Janoschka S, Takemaru K, Levine J, Ge S (2012) A role for primary cilia in glutamatergic synaptic integration of adultborn neurons. Nat Neurosci 15:399-405. CrossRef Medline

Kwon HB, Castillo PE (2008) Role of glutamate autoreceptors at hippocampal mossy fiber synapses. Neuron 60:1082-1094. CrossRef Medline

Laplagne DA, Espósito MS, Piatti VC, Morgenstern NA, Zhao C, van Praag H, Gage FH, Schinder AF (2006) Functional convergence of neurons generated in the developing and adult hippocampus. PLoS Biol 4:e409. CrossRef Medline

Li XG, Somogyi P, Ylinen A, Buzsáki G (1994) The hippocampal CA3 network: an in vivo intracellular labeling study. J Comp Neurol 339:181-208. CrossRef Medline

Macek TA, Winder DG, Gereau, RW 4th, Ladd CO, Conn PJ (1996) Differential involvement of group II and group III mGluRs as autoreceptors at lateral and medial perforant path synapses. J Neurophysiol 76:37983806. Medline

Manzoni OJ, Castillo PE, Nicoll RA (1995) Pharmacology of metabotropic glutamate receptors at the mossy fiber synapses of the guinea pig hippocampus. Neuropharmacology 34:965-971. CrossRef Medline

Markwardt SJ, Wadiche JI, Overstreet-Wadiche LS (2009) Input-specific GABAergic signaling to newborn neurons in adult dentate gyrus. J Neurosci 29:15063-15072. CrossRef Medline

Markwardt SJ, Dieni CV, Wadiche JI, Overstreet-Wadiche L (2011) Ivy/ neurogliaform interneurons coordinate activity in the neurogenic niche. Nat Neurosci 14:1407-1409. CrossRef Medline

Nakashiba T, Cushman JD, Pelkey KA, Renaudineau S, Buhl DL, McHugh TJ, Rodriguez Barrera V, Chittajallu R, Iwamoto KS, McBain CJ, Fanselow MS, Tonegawa S (2012) Young dentate granule cells mediate pattern separation, whereas old granule cells facilitate pattern completion. Cell 149:188-201. CrossRef Medline

Niibori Y, Yu TS, Epp JR, Akers KG, Josselyn SA, Frankland PW (2012) Suppression of adult neurogenesis impairs population coding of similar contexts in hippocampal CA3 region. Nat Commun 3:1253. CrossRef Medline

Overstreet LS, Hentges ST, Bumaschny VF, de Souza FS, Smart JL, Santangelo AM, Low MJ, Westbrook GL, Rubinstein M (2004) A transgenic marker for newly born granule cells in dentate gyrus. J Neurosci 24:3251-3259. CrossRef Medline

Overstreet Wadiche L, Bromberg DA, Bensen AL, Westbrook GL (2005) GABAergic signaling to newborn neurons in dentate gyrus. J Neurophysiol 94:4528-4532. CrossRef Medline

Overstreet-Wadiche LS, Bensen AL, Westbrook GL (2006a) Delayed development of adult-generated granule cells in dentate gyrus. J Neurosci 26 : 2326-2334. CrossRef Medline

Overstreet-Wadiche LS, Bromberg DA, Bensen AL, Westbrook GL (2006b) Seizures accelerate functional integration of adult-generated granule cells. J Neurosci 26:4095-4103. CrossRef Medline

Ratzliff Ad, Howard AL, Santhakumar V, Osapay I, Soltesz I (2004) Rapid deletion of mossy cells does not result in a hyperexcitable den- 
tate gyrus: implications for epileptogenesis. J Neurosci 24:2259-2269. CrossRef Medline

Ribak CE, Seress L, Amaral DG (1985) The development, ultrastructure and synaptic connections of the mossy cells of the dentate gyrus. J Neurocytol 14:835-857. CrossRef Medline

Sahay A, Scobie KN, Hill AS, O'Carroll CM, Kheirbek MA, Burghardt NS, Fenton AA, Dranovsky A, Hen R (2011) Increasing adult hippocampal neurogenesis is sufficient to improve pattern separation. Nature 472:466470. CrossRef Medline

Scharfman HE, Myers CE (2012) Hilar mossy cells of the dentate gyrus: a historical perspective. Front Neural Circuits 6:106. CrossRef Medline

Song J, Zhong C, Bonaguidi MA, Sun GJ, Hsu D, Gu Y, Meletis K, Huang ZJ, Ge S, Enikolopov G, Deisseroth K, Luscher B, Christian KM, Ming GL, Song H (2012) Neuronal circuitry mechanism regulating adult quiescent neural stem-cell fate decision. Nature 489:150-154. CrossRef Medline

Vivar C, Potter MC, Choi J, Lee JY, Stringer TP, Callaway EM, Gage FH, Suh $\mathrm{H}$, van Praag H (2012) Monosynaptic inputs to new neurons in the dentate gyrus. Nat Commun 3:1107. CrossRef Medline

Williams PA, Larimer P, Gao Y, Strowbridge BW (2007) Semilunar granule cells: glutamatergic neurons in the rat dentate gyrus with axon collaterals in the inner molecular layer. J Neurosci 27:13756-13761. CrossRef Medline

Zolotukhin S, Byrne BJ, Mason E, Zolotukhin I, Potter M, Chesnut K, Summerford C, Samulski RJ, Muzyczka N (1999) Recombinant adeno-associated virus purification using novel methods improves infectious titer and yield. Gene Ther 6:973-985. CrossRef Medline 